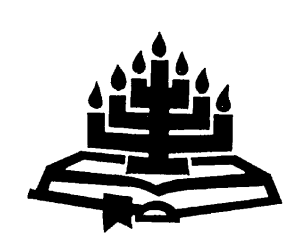

\title{
'n Etiek van Bybellees en 'n hermeneutiek van weerloosheid
}

\author{
G.F. Snyman \\ Departement Ou Testament \& Ou-Nabye Oosterse Studie \\ Universiteit van Suid-Afrika \\ PRETORIA \\ E-pos: snymagf@unisa.ac.za
}

\begin{abstract}
An ethics of reading the Bible and a hermeneutics of vulnerability

On the basis of Van der Walt's (2008) proposal regarding an approach towards Scripture, the author proposes a hermeneutics of vulnerability that aims to facilitate a Bible reading process "with" people and no longer "for" people. Such a hermeneutic will enable the Bible reader to take into account the effect a particular explanation of Scripture will have on people for which he or she need to take responsibility. In the ensuing discussion, firstly, the author looks at the way people are being made destitute by a particular reading of the Bible, and secondly, discusses how a hermeneutic of vulnerability reveals such a vulnerableness.
\end{abstract}

\section{Opsomming}

\section{'n Etiek van Bybellees en 'n hermeneutiek van weerloosheid}

$\mathrm{Na}$ aanleiding van Van der Walt (2008) se voorstel vir Skrifbenadering as brug tussen Skrifbeskouing en Skrifverklaring, stel die skrywer 'n hermenutiek van weerloosheid voor met die doel om 'n Bybelleesproses te fasiliteer waarvolgens daar nie meer vír mense Bybel gelees word nie, maar mét hulle. So 'n hermeneutiek stel die Bybelleser in staat om te sien wat die effek van 'n bepaalde Skrifverklaring op ander mense is en waarvoor hy of sy verantwoordelikheid moet neem. In die opvolgende bespreking word eerstens gekyk hoe 'n bepaalde soort Bybellees mense weerloos stel en tweedens hoe 'n hermeneutiek van weerloosheid hierdie weerloosstelling in die oopte bring. 


\section{Inleiding}

In sy artikel "Hoe moet 'n Gereformeerde teoloog met die Bybel omgaan?" maak Prof. Tjaart van der Walt (2008) 1 'n paar insiggewende opmerkings oor die hermeneutiek. Hierdie opmerkings verteenwoordig in 'n sekere sin hoe Van der Walt se hermeneutiek oor die jare verander het. Hy bely immers (Van der Walt, 2008:768) dat sy eksegetiese oogklappe afgeval het. Dit lyk of hy met min of meer dieselfde probleem gesit het as die een waarmee ek in 2006 (Snyman, 2006:715-718)2 geworstel het: Hoe wéét 'n mens wanneer 'n uitspraak in die Bybel ewigheidsgesag het? My antwoord verskil weliswaar van Van der Walt s'n, maar daar is ook aanknopingspunte.

Van der Walt (2008:757) vra of daar nie tussen Skrifbeskouing en Skrifverklaring 'n tussenskakel is nie. Só 'n tussenskakel sien hy (Van der Walt, 2008:770) in wat hy "Skrifbenadering" noem en wat die brug moet slaan tussen Skrifbeskouing en Skrifverklaring. Skrifbenadering moet uiteindelik die verskil in Skrifverklaring kan verklaar. Al het mense dieselfde Skrifbeskouing kan hulle as gevolg van verskillende Skrifbenaderings tot verskillende konklusies kom (Van der Walt, 2008:771). Skrifbenadering word as "Bybelgetroue, eg-wetenskaplike, onvervalsde Gereformeerde hermeneutiek" verstaan (Van der Walt, 2008:771).

$1 \quad$ Ek het 'n stam- en kerklike verbintenis met Prof. Tjaart van der Walt. Die stamverbintenis spruit voort uit sy huwelik met 'n niggie van my vader. Die kerklike verbintenis spruit voort uit die lidmaatskap van die GKSA. As kind het ek sy bevestiging as predikant in Krugersdorp meegemaak, en sy afskeidspreek toe hy as Professor in Nuwe Testament aan die Teologiese Skool Potchefstroom beroep is. Sy afskeidspreek toe hy Rektor van die PU vir $\mathrm{CHO}$ geword het, het ek oor die radio as jong student aan die destydse RAU gevolg. Wat my van dié preek bygebly het, is die term "hokkie-en-vakkie Christene", en sy siening dat 'n mens 'n geïntegreerde lewe moet lei. Professor Van der Walt is egter ook deel van die ouer garde wat jong mans soos ek (die "Boetman-geslag") grens en townships toe gestuur het om 'n ongeregverdige oorlog te veg. Die ervaring om ' $n$ ander se oorlog te veg, is 'n onlosmaaklike deel van my bestaan en vorm 'n deel van die konteks waarmee ek hom "lees" en vrae stel. Met hierdie artikel wil ek professor Van der Walt se denkskuiwe wat hy sedertdien gemaak het, vier, maar ek wil ook die geleentheid gebruik om kritiese vrae te vra ter wille van 'n broodnodige gesprek in die kerk oor ons verlede.

2 Dit het hier gehandel oor die aanwending van "tydgerigtheid" en "tydgebondenheid" in wat die Bybel oor homoseksualiteit sê. Janse van Rensburg het in dieselfde uitgawe op die artikel gereageer en gemeen dat my verstaan van die twee begrippe nie heeltemal korrek is nie. Hy (Janse van Rensburg, 2006:760761) meen egter dat ' $n$ mens by Paulus daarmee rekening moet hou dat die opdrag self die beginsel is indien daar geen beroep op 'n kultuur-historiese begronding kan wees nie. 
Maar wat in die "Skrifbenadering", oftewel hermeneutiek, lei tot verskillende verklarings van die Bybel? Ek wil een moontlike aanknopingspunt opper, wat verwoord kan word met die idee van teksbeskouing (Snyman, 2007:174). Terwyl Skrifbeskouing te make het met die gesag van die Bybel vir die geloof, hou teksbeskouing verband met die perspektiewe waarmee die Bybel as 'n teks benader word. Hieronder plaas ek alles wat met jou menswees verband hou soos opvoeding, ekonomiese welvaart, politieke ideologie, sosiale stand, 'n siening hoe die fisiese wêreld inmekaarsteek, geslagtelikheid, ouderdom, seksualiteit en geografiese gebondenheid. 'n Deel hiervan is ook filosofiese en kenteoretiese raamwerke waarmee die leser die Bybelteks benader.

Een van die bydraes van literêre teorië tot die eksegese van die Bybel is die opstel van 'n teksbeskouing. Amper 'n kwarteeu gelede het Botha (1986:279) aangedui hoe teksteoretiese uitgangspunte nie in botsing met 'n gereformeerde Skrifbeskouing is nie, maar eerder op 'n noodsaaklike uitvloeisel daarvan neerkom. Met die Bybel as "Woord van God" is die teks op die ou einde die knooppunt van die hele kommunikasiegebeure tussen God en die mens. Botha (1986:275-76) dui aan hoe die drie momente van die Bybelteks, naamlik die historiese, die strukturele en die teologiese juis met die gereformeerde Skrifbeskouing verband hou in terme van die openbaringshistoriese ontwikkeling van die Bybel as Woord van God, die taalkode waarin die Bybelteks geskryf is en die teologiese moment wat uit die selfgetuienis van die Bybel as teks na vore kom.

Terwyl daar net een gereformeerde Skrifbeskouing is, kan daar wel meer as een teksbeskouing wees (Botha, 1986:274). Tog lyk dit nie asof die gereformeerde hermeneutiek 'n onderskeid tussen 'n Skrifbeskouing en teksbeskouing aanvaar het nie (vgl. Van Deventer, 2010), maar eerder vanuit 'n bepaalde kenteoretiese raamwerk die twee laat saamval. Vanuit 'n positivistiese denkraamwerk word die Bybel as 'n objektiewe teks gesien. Die gevolg is dat aan die menslike van die begin af geen wesenlike bydrae toegeken word nie, hetsy in die totstandkoming van die Bybel as teks, hetsy in die interpretasie van die teks as Woord van God nie.

In aansluiting by Van der Walt se pleidooi vir 'n brug tussen Skrifbeskouing en Skrifverklaring, en ter wille van wetenskaplikheid en 'n onvervalsde hermeneutiek, wil ek 'n pleidooi lewer om die menslike aspek ook in die hermeneutiek te verreken. Die gedaante waarin ek dit wil voorstel, is 'n hermeneutiek van weerloosheid. Lidmate van die GKSA is op verskeie vlakke uitgelewer en weerloos gestel. Polities, met die verlies aan mag, is wit lidmate weerloos as dit kom by 
regstellende aksie en grondhervorming. Binne 'n samelewing wat op mikrovlak sterk patriargaal funksioneer, word vroue se stemme nie gehoor nie. Op ekonomiese gebied trek swart lidmate steeds aan die kortste ent. Terwyl die samelewing nog steeds grootliks gesegregeerd is, en die GKSA met God se genade hierdie segregasie probeer verbreek met ' $n$ nie-rassige geografiese verdeling in die kerkregeringstruktuur, is die vraag of ons ons rassigheid kán verbreek op kerklike vergaderings ${ }^{3}$ as ons aan die een kant in gebreke bly om ' $n$ duidelike skuldbelydenis oor apartheid te formuleer en volstaan met 'n verwysing na die GKSA se kritiek op apartheid, maar aan die ander kant tog meen dat nie alles onder apartheid so sleg was nie. Dit skep wantroue 4 en wek die indruk dat die kritiek nie diep genoeg gesny het nie, sodat die basis waarop apartheid berus het skynbaar nog funksioneer. 5

Onderliggend aan hierdie basis is ' $\mathrm{n}$ God wat aan mense rolle verskaf op grond van biologiese samestelling. Die afskaffing van apartheid het veroorsaak dat die rolle wat op grond van velkleur toegedig word nie meer aanvaarbaar is nie, maar rolle op grond van biologiese samestelling soos geslag wel aanvaar word. Daarom kan die vrou nie in die amp van ouderling of predikant wees nie. Kru rassisme het weliswaar verdwyn, maar indien die basis wat onderliggend aan apartheid lê nie die nek ingeslaan is nie, gaan verfynde vorms wel voorkom. In watter mate meen lidmate dat apartheid nie soseer verkeerd was nie, maar eerder net verkeerd toegepas is? God openbaar Homself immers op so 'n wyse dat Hy teen volke diskrimineer en hulle selfs laat uitroei. 6

$3 \quad$ Hierdie opmerking is na aanleiding van 'n gesprek op die gestorwe GKSA-forum en hoorsê-getuienis van wat op 'n streeksinode gebeur het. Die eerste het gehandel oor 'n ongelukkigheid omdat almal by 'n klassis nie die Afrikaanse psalms gesing het nie ten spyte daarvan dat almal wel die Zulupsalms gesing het. Die tweede was 'n waarneming dat ten spyte van die strewe na eenheid, die gesprek op 'n streeksinode op Afrikaans gevoer is, met die gevolg dat nieAfrikaansprekende broeders eenkant met 'n tolk gesit het. Dit het interaksie tussen swart en wit tog bemoeilik.

$4 \quad$ Uit koerantberigte blyk dit dat nie al die swart gemeentes deel wil wees van 'n verenigde struktuur nie. Daar skyn nog baie wantroue te wees.

Hexham (1981:195-196) verwys in hierdie verband na "the myth of apartheid".

6 Dit was een van die argumente wat teenoor my idees oor terreurtekste geopper is tydens 'n lesing by die GTV op 11 Augustus 2009. Lidmate stuit voor die feit dat die teks van God praat wat beveel dat die Kanaäniete uitgewis moet word. Dit word as godsopenbaring beskou wat nie geïgnoreer mag word nie. 'n Historiese, literêre en geïnformeerde lees wat die teks in sy oorspronklike 
Binne hierdie gespreksraamwerk wil ek 'n hermeneutiek van weerloosheid op die tafel sit met die doel om 'n Bybelleesproses te fasiliteer waarvolgens daar nie meer vír mense Bybel gelees word nie, maar mét hulle. So 'n hermeneutiek stel die Bybelleser in staat om te sien wat die effek van 'n bepaalde Skrifverklaring op ander mense het en waarvoor hy/sy verantwoordelikheid moet neem. Op hierdie wyse kan die basis van apartheid en die grondliggende beginsel wat diskriminasie van enige aard steun, hokgeslaan word. Anders gestel, 'n herkenning van weerloosheid wat veroorsaak word deur ' $n$ bepaalde manier van Bybellees, moet uiteindelik tot ' $n$ bepaalde hermeneutiek van openheid lei. Wanneer weerloosheid 'n houding word waarmee die Bybel gelees word, kan van voorregte afstand gedoen kan word. Sodoende kan die dienskneggestalte waana Van der Walt (2008:763) verwys, na vore kom.

In die opvolgende bespreking gaan eerstens gekyk word hoe 'n bepaalde soort Bybellees mense weerloos stel en tweedens hoe 'n hermeneutiek van weerloosheid hierdie weerloosstelling in die oopte bring.

\section{Wanneer ander weerloos gemaak word met goddelike sanksies}

\subsection{Hermeneutiese uitdaging}

Van der Walt (2008:758) rig die volgende waarskuwing: "Pasop vir die kortpad is-gelyk-aan-tekens, dat alles vandag nog blindelingsletterlik só gedoen moet word soos wat God dit eeue gelede in sy Woord beveel het." Wanneer ek egter Krüger en Jordaan (2009) se regverdiging van die 2009-Sinode se besluit om nie die vrou in die amp van ouderling en predikant toe te laat nie, lees, is dit presies wat gebeur het. Hulle beweer daar is 'n "direkte aanwysing" in die teks hoe die Here sy kerk wil regeer en "pertinente bevele" oor die vrou se posisie in die kerk en in die huwelik. "Die Skrifdele waarin geleer word dat vroue nie in die leer- of regeerdiens mag staan nie, is bedoel om as sodanig verstaan te word. Dit is 'n voorskrif vir alle tye." Janse van Rensburg (2006) se standpunt oor homoseksualiteit

verstaanskonteks probeer begryp en met die teks erns maak, staan voor 'n Godheid wat 'n volksmoord beveel. Hier staan ek dus voor 'n teologiese uitdaging. Dit is een ding om te aanvaar iets staan in 'n teks waarvan 'n mens nie hou nie, maar iets heeltemal anders om te meen dit is nie op jou eie lewe van toepassing nie (en dus nie godsopenbaring in jou lewe nie na aanleiding van Eseg. 18:23). 
kom ook hierop neer. ${ }^{7}$ Dit blyk ook een van die hoofargumente te wees in die boek Manlik en vroulik in die kerk: geslagtelikheid en die besondere dienste (Breed et al., 2008:66).8

Hierdie maatstaf van "direkte aanwysing" in die teks skep vir my morele en godsdienstige probleme wanneer ek sekere tekste in die Ou Testament begin lees soos die intogverhale in Joshua 1-12. Die kern van hierdie verhale is God wat Joshua en sy leër beveel om die inwoners van die Kanaänitiese dorpe uit te wis, omdat hulle Kanaäniete is. Wat hiermee gemaak as gelowige wat onder apartheid grootgeword het en deur amper vier eeue se kolonialisme en Westerse imperialisme bevoordeel is? Trouens, wanneer ek die teks as direkte aanduiding móét lees, moet ek nie dan eerder die posisie van die Kanaäniete inneem, synde die wederregtelike besetter van grond te wees wat nie aan my behoort nie, en wat dus nie moet huil oor regstellende aksie of grondhervorming nie?

Thelle (2007:72) meen sulke tekste plaas die gelowige voor 'n hermeneutiese en teologiese uitdaging, want sulke tekste word nog steeds gebruik om 'n regverdiging te bied vir ideologieë wat die potensiaal het om geweld aan te blaas. Die uitdaging is hoe om hierdie tekste te gebruik, oftewel (Janse van Rensburg, 2007:76) "how do we address the challenges posed by the fact that a text that states that God commands mass killing is part of an authoritative sacred text?" Daar is tradisies wat die tekste weliswaar as deel van die kanon beskou, maar min het dit gebruik as 'n program vir volksmoorde en landbesetting. Tog het dit wel gebeur (in Suid-Afrika weliswaar sonder volksmoorde).

In die VSA, gedurende die tyd van Europese besetting in die sewentiende eeu, het die Puriteine hierdie tekste gebruik om volksmoord teenoor die Indiane te regverdig deur laasgenoemde met die Kanaä-

$7 \quad$ Janse van Rensburg $(2006: 757,760)$ gee die volgende kriteria: 'n saak moet deur die hele Bybel voorkom ("deurlopend, onveranderd en onverdun") en daar moet "duidelike merkers" in die teks wees wat aandui dat 'n bepaalde optrede vir 'n bepaalde situasie geld met 'n motivering deur 'n dieperliggende beginsel.

8 Die skrywers (Breed et al., 2008:40, 66) meen dat God in sy Woord aan die eerste hoorders of lesers bekend gemaak het hoe hulle hulle lewe te midde van die destydse omstandighede moes inrig. Die Here het ook aangedui watter gedragswyses volgens sy wil is. Hierdie gedragswyses word as openbaring van God beskou ten opsigte van watter optrede en perspektiewe volgens sy wil is en dit bly geldig ongeag samelewingskonvensies (menslike offers, homoseksualiteit, aspekte van slawerny, poligamie - gevalle waar duidelike aanwysings aanwesig is). Vergelyk Snyman (2010) vir 'n verdere bespreking hieroor. 
niete te vereenselwig en die setlaars met die Israeliete (Thelle, 2007:74). Hier te lande het 'n boek soos Deuteronomium die teologiese fondament vir apartheid gebied (Deist, 1994). Dit het al begin toe die Voortrekkers hulleself met die Israeliete begin identifiseer het en die swart bevolking as die Kanaäniete beskou het, hoewel die idee van uitwissing nooit regtig posgevat het nie. In die dertigerjare van die vorige eeu het hierdie idees die basis vir afsondering begin vorm. Thelle (2007:75) beskou dit as "a grave example of how potentially dangerous it is to appropriate biblical texts to legitimize or even generate modern ideological programs".

Dit is opmerklik dat voor die vestiging van die staat Israel in 1948, die Palestyne geen probleme met die boek Joshua ondervind het nie. Na 1948 was daar 'n sterk neiging om die boek as Sionisties te verwerp, terwyl sekulêre Sioniste die Hebreeuse Bybel weer omarm het en die intog aangewend het om 'n nasionale identiteit te vestig (vgl. Lohfink, 1998). Hierdie groepe vind ondersteuning van konserwatiewe Christene wat die Joodse staat ondersteun asof laasgenoemde die wederkoms van Christus sou bespoedig.

Prior (1997:39) is van mening dat die teologiese gesprek oor die intog in die Beloofde Land en die hedendaagse teenwoordigheid van die Israeli's in Palestina die lotgevalle van die inheemse bevolkings voor elke besetting ignoreer. Volgens hom het die idee dat die Here die Israeliete die Kanaäniete laat doodmaak het, "sanctioned the British conquest of North America, Ireland and Australia, the Dutch conquest of South Africa, the Prussian conquest of Poland and the Zionist conquest of Palestine."9 $\mathrm{Hy}$ is ook van mening dat '[t]he absence of concern for 'the natives' reflects the deeply ingrained Eurocentric, colonialist prejudice which characterizes virtually all historiography, as well as the discipline of biblical studies".

Binne Ou-Testamentiese teologiese geledere is Von Rad (1982) se behandeling van die Kanaäniete in sy monumentale Old Testament theology 'n goeie voorbeeld hoe Bybelwetenskaplikes ook die inheemse bevolking van 'n bepaalde gebied geïgnoreer het. Von Rad

It should perhaps not come as a surprise that the examples of misappropriation of the biblical conquest account in modern times that we have seen examples of above all come from immigrant-settler states like America, South Africa and Israel. These are countries that are all highly ideological and are founded on the construction of a common experience and a very high level of awareness of identity. 
(1982:122) verwys na 'n credo in Deuteronomium 26:5-9 waar die Here die land aan Israel beloof het. Die credo is 'n geloofsbelydenis wat die hoofmomente van Israel se heilsgeskiedenis saamvat van die aartsvaders tot by die intog. 10

Die probleem is dat Von Rad die teenwoordigheid van die Kanaäniete in die land van melk en heuning heeltemal verswyg. Hoekom? Brueggemann (2002:413) is van mening dat Von Rad nie juis anders kon as om die Kanaäniete te ignoreer nie, omdat hy 'n polemiek teen Nasionaal-Sosialisme gevoer het. Sy solidariteit moes dus by Israel gewees het, en by implikasie, ook by Israel in die Bybel.

It seems clear that von Rad, in the shadow of the Barmen Declaration, sought to provide 'confessing' standing ground for the church against National Socialism. He did so by postulating that ancient Israel had to find confessional standing ground against the deep and pervasive threat of Canaanite 'fertility religion'. Having established that 'Canaanite religion' was a counterpart to National Socialism, already in 1936 von Rad concluded that 'creation' was an extraneous theme in the Old Testament and not central to its recital of faith. He apparently made this judgment on the basis of and in response to the 'Blood and Soil' claim of National Socialism that was in its own way a 'fertility religion', albeit Aryan.

Levinson (2008:238) meen ook dat 'n mens nie Von Rad se sosiopolitieke posisie kan ignoreer nie. Von Rad se lees van Deuteronomium as 'n reeks preke wat moet stig en aanmoedig, moet verstaan word in die lig van sy pos by die Universiteit van Jena in 'n tyd onder Nasionaal-Sosialisme waartydens die Ou Testament meer en meer verdag geraak het.

Hierteenoor is daar mense soos Ateek (1991), 'n Palestynse Christen, en Warrior (1999), 'n Amerikaanse Indiaan, wat weer op aangrypende wyse illustreer hoe die een se bevryding die ander se onderdrukking word wanneer die Kanaäniete in die lees- en verstaansproses geïgnoreer word.

10 Desnieteenstaande is Von Rad (1982:296-297) se probleem dat die Heksateug se weergawe van die landgawe verskillende historiese en teologiese tradisies bevat wat in verskillende tye op verskillende plekke ontstaan het. Hy sien sy taak daarin "to sketch out the main versions and concepts which accumulated around this event in the saving history". 


\subsection{Twee voorbeelde van weerloosmaking van die ander}

Ateek (1991:281) beskryf hoe die Bybel vir bevrydingsteoloë 'n bron van krag is wat oplossings verskaf en tot redding lei, maar terselfdertyd vir Palestyne onderdrukking eerder as vryheid bied. Hy vra byvoorbeeld aan Christene aan watter Israel hulle dink en watter soort redding hulle in gedagte het wanneer hulle in die Anglikaanse liturgie die Benedictus met die openingslyn, Blessed be the Lord God of Israel, for He has visited and redeemed his people, opsê. Ateek lê uiteindelik op die sosiopolitieke ligging van die Bybelleser klem. Dit is van uiterste belang in die konteks van die Palestynse Christene waar die Eksodusverhaal en die intog in die beloofde land as model vir bevryding ongeskik is:

For Palestinian Christians, the core question that takes priority over all others is whether what is being read in the Bible is the Word of God to them and whether it reflects the nature, will, and purpose of God for them. In other words, is what is being read an authentic insight from God about who God is? [...] Conversely, is what is being heard a reflection of authentic human understanding about God at that stage of development? Or, to put it bluntly, is it basically a statement from humans put into the mouth of God, that has become confused as an authentic message of God to people? (Ateek, 1991:281.)

In Warrior se vergelyking tussen dit wat die Kanaäniete beleef het onder die hande van Israel en sy eie mense (Osage Amerikaanse Indiane) se onderwerping aan Europeërs, illustreer die merke wat op mense gelaat word wanneer die Bybel gelees word sonder om die konteks van die leser of diegene vir wie gelees word, in ag te neem. Warrior (1991:288) verstaan hoe 'n onderdrukte groep soos die Afrikaan-Amerikaners krag uit die Eksodusverhaal kon put deur 'n God te vind wat aan hulle kant was, al is Hy met die onderdrukkers geassosieer. Maar sy probleem lê by wat met die Kanaäniete gebeur het (Warrior, 1991:289):

The land, Yahweh decided, belonged to these former slaves from Egypt and Yahweh planned on giving it to them - using the same power used against the enslaving Egyptians to defeat the indigenous inhabitants of Canaan. Yahweh the deliverer became Yahweh the conqueror.

Warrior (1991:291-292) noem dit 'n genadelose uitwissing van die inheemse bevolking en

[...] reflect[s] a situation in which indigenous people put their hope in a god from outside, were liberated from their op- 
pressors, and then saw their story of oppression revised out of the new nation's history of salvation. They were assimilated into another people's identity and the history of their ancestors came to be regarded as suspect and a danger to the safety of Israel. In short, they were betrayed.

Dit wat Warrior sien wat met die Kanaäniete gebeur het, het sy mense persoonlik ervaar. ${ }^{11}$ Vandaar die gevoel van verraad en die perspektief op Jahwe as bevrydende én seëvierende of triomfalistiese Godheid:

No matter what we do, the conquest narratives will remain. As long as people believe in the Yahweh of deliverance, the world will not be safe from Yahweh the conqueror. (Warrior, 1991: 294.)

Hoe moet 'n mens Ateek en Warrior se opmerkings verstaan? Vir albei is die intoggeskiedenis ' $n$ geskiedenis van terreur en skep die boek Joshua vir hulle 'n probleem, want God gee opdrag dat die Kanaäniete uitgeroei word. Immers, om Kruger en Jordaan se woorde te gebruik, daar is direkte aanduidings daarvoor in die boek dat Israel Kanaän kan beset. Die teks skep 'n probleem vir daardie lesers wat hulle met die lotgevalle van die inheemse inwoners op daardie stadium vereenselwig. Vir diegene wat hulle met Israel vereenselwig, is die teks nie 'n probleem nie, omdat hulle hulle skaar by die magsperspektief in die teks. Dit is egter hier waar ' $n$ dekoloniale perspektief12 die leser se sosio-politiese ligging mag ontmasker. Indien die leser hom/haar by Israel skaar, is die anneksasie van Kanaän nie problematies nie, want dit word deur God gewil. Is die simpatie egter met die Kanaäniete, word die intog in Kanaän 'n probleem, veral vanuit die ervaring van die geskiedenis van kolonialisme en imperialisme.

11 Warrior (1991:293) spoor lesers aan om die intogverhale ernstig op te neem, want in die kommentare en kritiese werke word die Kanaäniete nie ernstig opgeneem nie. Wanneer hierdie tekste te berde kom, wy die wetenskaplikes min aandag aan die status van die inheemse bevolkings en hulle regte as mense en as nasies. Die verowering en die intog in die Beloofde Land word "just one more redemptive moment rather than a violation of innocent peoples' rights to land and self-determination".

12 'n Dekoloniale perspektief het ten doel om die gevolge van die magsverhoudings wat onder kolonialisme ontstaan het en onder die postkoloniale bedeling voortduur, vanuit die oogpunt van die gekoloniseerde te analiseer (vgl. Quijano, 2007). 


\subsection{Die teologiese uitdaging}

lemand soos Prior (1997:291) is uitdagend skerp oor die soort Bybelgebruik wat die intog as model aanwend vir moderne vorms van imperialisme, juis omdat dit geweldige lyding in die wêreld veroorsaak (het).

Meanwhile, a God who insists on the destruction of people as an act of devotion to him is one from whom most decent people should recoil. The biblical doctrines of God's Chosen People and Promised Land assume a problematic character when viewed against the colonialist exploitation of them leading to the exploitation of the indigenous peoples of Latin America, the humiliation of non-whites [sic] in South Africa and, in our own day, to militaristic and xenophobic Zionism, which undermines the integrity of Judaism, embarrasses and shocks most moral people and wreaks havoc on an innocent third party. ${ }^{13}$

Warrior (1991:290) besef terdeë dat die verbond wat die Here met Abraham en sy nageslag gesluit het, $\mathbf{1 4}$ bevryding sowel as verowering insluit. In Genesis 12:6-7, wanneer die verbond gesluit word, kom die leser immers agter dat Abram op daardie stadium in 'n vreemde gebied is en dat die inwoners van daardie gebied nie weg is nie. Abram en Lot gaan selfs verder en verdeel die land tussen mekaar terwyl die land nog ander inwoners gehad het. In Genesis 15:13-14 weet die leser selfs dat die land wat so aan Abram beloof is, in ander hande is. Maar Abram tree op asof hulle nie bestaan nie.

Met die inwoners nog in die land, is die vraag hoe Abraham se nageslag dan die land gaan bekom. Deuteronomium 7:12 noem by wyse van inname. Die Here sal die inwoners oorgee aan die Israeliete. Die Israeliete sal hulle vernietig en geen genade sal betoon word nie. In Eksodus word die belofte herhaal (Eks. 3:8; 6:2-4). Wanneer Israel dan inderdaad uit Egipte padgee, lees ons dat die inwoners van die beloofde land met vrees vervul word (Eks. 15:1-

13 Die verwysing na "non-whites" verraai Prior se eie sosio-politieke posisie, naamlik onteenseglik deel van daardie deel van die wêreldbevolking wat wit is. Prior was 'n bevrydingsteoloog, maar sy gebruik van whiteness as norm is dalk in ooreenstemming met die erfenis van Britse imperialisme en die konstruksie van die werklikheid wat nog steeds daaruit voortvloei!

14 Die belofte van die land in Genesis 17:5-8 word hernu aan Isak in Genesis 26:34 en aan Jakob in Genesis 28. Toe Josef sterf, vra hy dat sy beendere gebring word na die land wat die Here gesweer het om aan Abraham, Isak en Jakob te gee (Gen. 50:24). 
16). Boonop stuur die Here sy engel vooruit om hulle met pes uit te dryf (Eks. 23:23, 28). Die Here gee die Kanaäniete aan Israel oor wat hulle met 'n groot slagting verdryf.

In Levitikus bevestig die Here die verbond met Israel met die land as 'n gawe. Hulle word egter ook opgeroep om hulle af te skei of van die res van die bevolking in die beloofde land af te sonder (Lev. 20:22-27). In Numeri lees ons van weerstand en hoe die Here daardie Kanaäniete aan Israel oorgee (Num. 21). So word Midian vernietig met elke man wat gedood word en elke vrou en kind wat as slawe weggevoer word. Vee word gebuit en die dorpe word tot op die grond verbrand. Moses was ontsteld omdat die vroue en kinders gered is en hy beveel hulle teregstelling (Num. 31).

Die uitwissing het in die boek Deuteronomium voortgegaan. Trouens, uitwissing het hier 'n bevel geword, want as dit nie gedoen sou word nie, sou dit die Here se toorn teen Israel laat ontvlam het. Uitwissing het ook beteken dat Israel nie met die omliggende volke mag meng nie en ook hulle gode moes uitroei (Deut. 7). In Deuteronomium 9 word Israel van alle blaam onthef en word die uitwissing voor die Kanaäniete se eie deur gelê. Joshua beskryf in detail wat die militêre operasies teen die Kanaäniete behels het, terwyl Rigters weliswaar 'n ander prentjie gee en aandui dat die verdrywing van die Kanaäniete nie so suksesvol was nie.

Terwyl Ateek en Warrior hulleself met die swartskaap in die intogverhaal geassosieer het, het die Calvinistiese tradisie ditself met die lotgevalle van Israel geassosieer.15 Dit kon nie anders nie, omdat die Bybel as ' $n$ welwillende boek as Woord van God opgeneem is. Hexham (1981:4) wys hoe apartheid uiteindelik as 'n rasse-ideologie op verskeie aspekte van Calvinisme gekonstrueer is, veral na aanleiding van die effek wat die nederlaag van die Anglo-Boereoorlog op die Afrikaner gehad het. Hy (Hexham, 1981:115) wys op die invloed van Abraham Kuyper en Groen van Prinsterer wie se

15 Ek kan nie ontken dat die Calvinistiese tradisie waarin ek opgegroei het en wat deel van my erfenis is, inderdaad deel is van 'n Europese imperialisme wat hier in Afrika wortel geskiet het nie. Hierdie perspektief kan egter veroorsaak dat ek as gelowige die Bybel op so 'n manier hanteer dat ander mense kan seerkry. Indien 'n mens met Israel vanuit die geloof identifiseer, is dit moontlik om jouself aan die maghebber in die teks se kant te skaar. Dit is gevolglik moontlik om nie 'n sensitiwiteit te ontwikkel vir daardie karakters in die teks wat onder die meule kom as gevolg van die maghebber se magsuitoefening nie. Is dit moontlik om binne 'n gereformeerde raamwerk die verhaal van die intog vanuit die Kanaäniete se perspektief te lees? 
benaderings aan die gemeenskap die instrumente verskaf het om 'n Calvinistiese gemeenskap soortgelyk aan dit wat in Nederland bedink is, te vestig. Die Voortrekkers het hulleself as mense beskou wat deur God uitverkies is om die evangelie aan die Suidpunt van Afrika te kom verkondig. Maar Afrika is die donker kontinent, en hulle moes die duisternis kom verbreek het. Die bevordering van die koninkryk het saamgeval met die Afrikaner se triomf. Die Afrikaan is egter nie bekeer of ingetrek nie, maar gebreek en onderdanig gemaak, meen Hexham (1981:59). Selfs die Engelse is skynbaar uit die koninkryk uitgesluit.

Van der Walt (2008:762) vra na aanleiding van die uitsluiting van die Afrikaan die volgende: "Hoe kan ons mede-Afrikaners en ook ander medeburgers nie die geleentheid, die roeping, sien en dit met albei hande aangryp nie? Wat het ons mense met blindheid geslaan?" Hy antwoord: "'n kortsigtige, naakte selfsug ... Afrikaner-nasionalisme het die kitaar geslaan ..." 'n Paar Gereformeerdes het egter so 'n roeping gesien en die Koinonia-verklaring na die dood van Steve Biko onderteken, maar hulle het onder eie geledere teenkanting gekry.

Oor die Koinonia-verklaring oordeel Hexham (1981:196-197) die volgende:

The Koinonia Declaration is a strange document, at once conservative and radical. It is conservative in its deference to authority and its faith in the good will of the Government. It is radical in its implications. Yet it is a document which could only have been created by people convinced of the myth of apartheid. Although highly critical of the practice of apartheid and Nationalist actions generally, it nevertheless, unlike statements issued by the Christian Institute and other oppositions groups, never questions apartheid as a grand theory and the ultimate solution of South Africa's problems. [...] What they rejected was the way the myth of apartheid had become incarnated, but not the myth itself. They might be willing to allow inter-racial marriage only because they did not think a few such marriages really threatened the integrity of the state. Therefore they were willing to attack a law which violated their fundamental principle of sphere sovereignty.

As Van der Walt (2008:762) egter sê, "alles van die apartheidsera was nie net sleg nie, onregverdig, selfs demonies nie", wil hy nog iets van apartheid red? Apartheid was inderdaad materieel goed vir die Afrikaner, maar nie vir diegene wat uitgesluit is nie. Het dit nie dalk tyd geword om die mite van apartheid wat deur die Suid- 
Afrikaanse weergawe van Calvinisme aangehelp is (Hexham, 1981: 197-198), die nek om te draai nie? Afrikanernasionalisme het nooit juis Calvinisme geïnternaliseer nie. As Christene het hulle toegelaat dat hulle deur die Calvinistiese elemente van die apartheidsmite vasgevang word, maar die mite is grotendeels binne die raamwerk van nasionalisme ontvang en nie binne die Calvinisme nie. Binne die Calvinisme was Christelikheid egter die hoofkomponent van hulle identiteit, en nie die nasionalistiese ideaal nie.

Min mense sal ontken dat die teologiese regverdiging van apartheid tot die pyn en lyding van miljoene mense in Suid-Afrika gelei het. Prior (1997:292) meen dat die probleem in die Bybeltekste lê. Hy meen die poging om die probleem te verskuif na die benadering, oftewel die lesers se vooroordele en voorbehoude, is 'n manier om die probleem van die teks te ignoreer. Hy (Prior, 1997:292) is reg wanneer hy stel dat die probleem in die teks self is.

[...] containing menacing ideologies and racist, xenophobic and militaristic tendencies, and is dangerous when read without respect for its literary genre and the circumstances of its composition. The moral problem stems from the nature of some of the material of the Bible itself.

Die teks is juis 'n probleem vanweë die subjektiwiteit waarmee die leser na die teks toe kom. 'n Leser wat sterk aan die welwillendheid van die Bybelteks glo, gaan die teks anders benader as iemand wat weerloos gestel is as gevolg van die aanvaarding van "menacing ideologies" in die waan dat dit goed bedoel is. Die geskiedenis van die hermeneutiek wys dat daar op die oomblik vir elke normatiewe Bybellees ' $n$ afwykende interpretasie na vore kom vanuit daardie groepering wat deur die norm weerloos gemaak word.

\section{Hermeneutiek van weerloosheid}

\subsection{Maatstaf}

Die norm wat op die oomblik in die wêreld vir Bybellees aangewend word, is die perspektief van wit, Westerse, heteroseksuele, welgestelde, Christelike mans. Wanneer 'n mens na die agendas van die gematigde Amerikaanse Society of Biblical Literature of die meer godsdienskritiese American Academy of Religion gaan kyk, is dit 
duidelik dat vir elke benoeming van hierdie maatstaf daar 'n groep mense is wat uitgesluit voel. 16

- Daar is hermeneutiek wat deur etniese benamings gekwalifiseer word soos Latyns-Amerikaans, African-American, Asiaties, of selfs Black, wat op hulle beurt suggereer dat die norm hulle uitsluit. Immers, hoekom hulleself so benoem indien die norm hulle nie sou uitsluit nie? Uit hierdie benamings kry 'n mens die indruk dat die norm witheid is en dat dit sekere groepe nie in ag neem nie.

- Postkoloniale Bybelleesgroepe by die Society of Biblical Literature veronderstel 'n Westerse Christendom wat in die koloniale tydperk as norm gegeld het en nog steeds geld met die uitbreiding van Amerikaanse imperialisme waarteenoor standpunt ingeneem moet word.

- Die waagmoed om queerteologie openlik te bedryf en as lesbiese, gay, biseksuele en transseksuele mense 'n Christelike geloof te bely, bevraagteken heteroseksualiteit as norm.

- Die volharding van die bevrydingsteologie in 'n postkoloniale periode met die gepaardgaande fokus op armoede, vestig die aandag op die vraag in watter mate normgewende Bybellees nie deur welgestelde Bybellesers gedoen word nie.

- Die fokus op Holocaust- en post-Holocaust-studies bring die Christendom se aandeel in die Holocaust en die voortslepende anti-Semitisme onder die vergrootglas.

- Die gevestigdheid van feminisme as 'n geldige perspektief om die Bybel mee te lees, bring die vraag na manlikheid en patriargie na vore.

Die bestaan van hierdie groepe in reaksie op die norm is moontlik 'n aanduiding van hoe die maatstaf ander mense wat nie daaraan kan

16 Vir 'n bespreking van hierdie "mythical norm", vergelyk Anderson (2009:135139):

This mythical norm constitutes the normative perspective that shapes the accepted (conservative) Christian religious policies and biblical interpretations. The implicit, if not explicit, adoption of this norm has created "the Other", a term that refers collectively to all the groups that are different based on race, gender identity, sexual orientation, religion, or class.

Vergelyk ook Escobar, 2007:200. 
voldoen nie, weerloos stel. Om een voorbeeld te noem: hoe kan 'n Palestynse Christen (vgl. Ateek, 1991) die Ou Testament lees met verhale soos die intog waar die Kanaaniete verdryf word en waar hierdie verhaal nog steeds aangewend word om hulle reg op 'n grondgebied te misken? Hoe moet 'n Amerikaanse Indiaan (vgl. Warrior, 1991) hierdie verhaal ten aansien van Westerse Imperialisme wat deur hierdie verhale gevoed is, lees? Word in bogenoemde gevalle nie, na aanleiding van Van der Walt (2008:757), gepoog om die Here vir die eie saak in te palm nie? Van der Walt vra eerder dat die Bybelleser sal seker maak dat die Skrifverklaring en Skriftoepassing aan die Here se kant is. ${ }^{17}$

Hoe geldig is hierdie maatstaf vir die GKSA? Gereformeerdheid is in 'n Europese tradisie gewortel. In die mate wat hierdie tradisie invloed het, sal die GKSA nie weerloos wees nie, maar eerder vanuit 'n magsposisie optree. Maar synde in Afrika, het hulle (in die woorde van Antjie Krog, 2009:100) "a unique opportunity to remove themselves from under the umbrella of the international sanctity of the white body and share the vulnerability of the black body." Hier kom egter ' $n$ dubbele weerloosheid na vore. Ten aansien van die oormag in so 'n sinode in terme van ras, gaan swart verteenwoordigers veral weerloos voel. Maar in die mate wat 'n swart politieke meerderheid hulle mag al hoe meer sigbaar maak, gaan 'n groep wit lidmate in die GKSA weerloos gestel word as gevolg van regstellende aksie en landhervorming.

\subsection{Weerloosheid}

Weerloosheid het met uitsluiting te doen. 'n Hermeneutiek van weerloosheid het te doen met die vraag in watter mate die Bybelleesproses uitsluiting van watter aard ook al tot gevolg mag hê. Hierdie uitsluiting of weerloosheidstelling berus op die aanwending van 'n maatstaf waaroor die weerloses geen beheer het nie, naamlik velkleur, geslag, geslagtelikheid, ensovoorts.

17 Van der Walt (2008:761) illustreer dit baie duidelik met die kwessie van slawerny waar selfsugtige eiebelang met behulp van 'n letterlike, kontekslose en ahistoriese interpretasie hierdie instelling laat oorleef het! Hy het nogal 'n rare (vir iemand in die GKSA) oog vir die historiese met sy erkenning dat die Bybel nie in 'n tydlose lugleegte tot stand gekom het nie en dat die wêreld nie stilgestaan het nie (Van der Walt, 2008:758). Hy meen egter dat historiese sensitiwiteit nie die blywende en die standvastige altydgeldende waardes mag ignoreer nie. 
Die idee van 'n hermeneutiek van weerloosheid is gebaseer op dit wat Levinas18 (1985:89) die "etiese moment" noem. Hiermee betrek hy die ander persoon, of in terme van hierdie gesprek, die een vir wie 'n mens Bybellees (die lidmaat by huisbesoek, die katkisant), of namens wie 'n mens Bybellees (lidmate wat nie by 'n sinode verteenwoordig word nie), maar teenoor wie 'n mens op die een of ander manier verantwoording moet doen. Die basis waarop hy werk, is die sesde gebod: "Jy mag nie doodslaan nie." Die etiese moment ontstaan in die ontmoeting tussen twee mense van aangesig tot aangesig ongeag die rede daarvoor. In hierdie ontmoeting word die ander persoon, metafories gesproke, deur die self ontmoet, sonder enige verwantskap, hetsy familie-, bloed- of gemeenskapsverwantskappe.

Hierdie ontmoeting moet nogal bedink word in terme van die besware wat die profete (Jes. 1:23; 10:1-2; Jer. 7:4-16) teenoor Israel en Juda gehad het ten aansien van hulle hantering van die armes, die weduwees en die wese. 19 Hulle is telkens verwaarloos, sodat die gemeenskap voortdurend opgeskerp moes word om na hulle om te sien. Die vrou se regsstatus was van so 'n aard dat sy weerloos was wanneer haar man gesterf het. Sy kon nie erf nie en het nie wyse gehad om haarself te onderhou nie. Sy kon ook nie na haar ouers teruggaan nie, want 'n bruidskat was reeds betaal. 20

Die gemeenskap se verpligting teenoor die armes, wese en weduwees loop soos 'n goue draad deur die Ou Testament en word ook met die verbond 21 in verband gebring. Waar dit skynbaar in die $\mathrm{Ou}$

18 Levinas is 'n filosoof wat die Russiese Revolusie van 1917 ontvlug het en in Frankryk herberg gekry het. In sy kritiek op Westerse denke meen hy dat die self verantwoordelik is vir die ander sonder 'n verwagting van wederkerigheid. Wederkerigheid is die ander se eie verantwoordelikheid waarop hy nie kan aanspraak maak nie.

19 Die ideale koning het omgesien na die weduwees, wese en die armes (Patterson, 1973:227; Fensham, 1962). Patterson (1973:226-228) verwys ook na die omliggende gebiede (Mesopotamië, Egipte en Sirië-Palestina) waar die koning as verteenwoordiger van die godheid se geregtigheid, reg aan die wese, weduwees en armes moet laat geskied.

20 Deist (2000:266) sê weduweeskap "means to be vulnerable, exploitable, insecure (cf. $1 \mathrm{Kgs} .17 .10-12$; Job 24.3, 21; Ps. 94.6; Isa. 1.23), sometimes even disgraced (cf. Isa. 54.4)".

21 Dit is daarom erg om te verneem dat hierdie verpligtings nie na ander bevolkingsgroepe gestrek het nie, want met die intog is die Kanaäniete tot die armes, weduwees en wese sonder die nodige versorging gereduseer! 
Testament net vir die verhouding binne Israel gegeld het, word dit by Levinas meer algemeen-geldend. Hoe dit ook al is, die ontmoeting is een tussen mense wat van alles gestroop is en wat kwesbaar, ontbloot en nakend is. Die ander wat ontmoet word, is soos ' $n$ vreemdeling in jou geledere, iemand wat nie deel is van die groep nie. Vir Levinas (1985:83) is dit selfs van so 'n aard dat al nooi die vreemde gesig jou uit om tot geweld oor te gaan, daar weliswaar die verbod op doodslag is.

Om die ander nie "dood te slaan" nie bevestig 'n radikale verpligting wat op elke persoon berus, soveel so dat Levinas meen dit gaan selfs kritiese denke vooraf terwyl dit eweneens kritiese denke beïnvloed. Die aangesig van die ander vorm die basis van die mens se verantwoordelikheid (Snyman, 2007:133). Daardie gesig wat ontmoet word, lê 'n radikale verpligting op die self om nie die ander gesig op watter wyse ook al te oorweldig of te vernietig nie. Die teenwoordigheid van die ander keer die mens om die ander een te oorweldig.

Maar ' $n$ mens hoef nie die ander persoon fisies aan te rand of dood te maak nie. Oorweldiging of vernietiging kan ook plaasvind wanneer die ander se verskil en andersheid genegeer word. Levinas (1969) noem dit totalisering. Dit gebeur wanneer die een die ander se outonimiteit ontneem. Dit gebeur wanneer mense op grond van hulle "wese" beoordeel en geoordeel word. In rassisme kom dit voor wanneer alle swartes of wittes oor dieselfde kam geskeer word en waar 'n optrede direk met die wese van die groep (velkleur) in verband gebring word. Dieselfde gebeur wanneer sosiale rolle aan mans en vroue toegedig word na aanleiding van hulle seksuele rolle.

Philips en Fewell (1997:4) sê:

[w] are obligated - before we think, before we critically analyze or conceptualize - to something/someone other than ourselves. And it is in the face of the Other (the one who escapes any horizon or conceptual scheme I might wish to impose upon it) that the experience of this obligation to be responsible for the other is concretely and practically discovered. In the face, the look of the eye, we meet responsibility.

Dit is in die ontmoeting met die ander wat die self ' $n$ kwesbaarheid (die ander kan die self eweneens vernietig) en 'n nabyheid ervaar (Levinas, 1981:85) waardeur die self hom/haar in die posisie van die ander plaas, en as 't ware die ander se gyselaar word (Levinas, 1981:127). Sodoende word die self deur die ander gedefinieer. 
Vanuit hierdie perspektief kan daar ernstige bedenkings geopper word wanneer 'n kerklike vergadering, wat net uit mans bestaan, 'n besluit neem oor vroue sonder dat die vroue teenwoordig is of as groep hulle mening gelug het. ' $n$ Besluit oor mense in hulle afwesigheid kom neer op 'n onvermoë om verantwoordelikheid te aanvaar vir diegene wat deur die besluit geraak word (vgl. Snyman, 2007: 134):

Dit is duidelik dat die groep manlike maghebbers geen radikale verpligting voel teenoor die vrou nie, omdat die vrou na haar 'wese' geskat word. Haar biologiese of fisiologiese samestelling, naamlik om kinders te baar, verdoem haar skynbaar tot seker posisies in die samelewing. Dit is asof die 'aard' van vroue hulle nie toelaat om in sekere dienste te mag tree nie.

Die weerloosheid van die vroue lê juis daarin dat hulle, ten spyte van stemreg, uit die besluitnemingstruktuur van die GKSA geweer word. Op hierdie manier word daar strukturele geweld teenoor hulle via die kerkreg gepleeg. Hierdie onreg en gevolglike weerloosheid word nie verdoesel deur wat Van der Walt (2008:769) "vrome begrippe" (en ek sou wou byvoeg, vrome rituele) noem nie.22

\section{3 'n Hermeneutiek van weerloosheid}

'n Hermeneutiek van weerloosheid staan in spanning met 'n magsuitoefening deur middel van Bybelinterpretasie. Laasgenoemde gebeur wanneer van die weerloses verwag word om bloot te aanvaar wat op 'n outoritêre wyse deur godsdienstige leiers aan hulle oorgedra word (Snyman, 2007:121). 'n Hermeneutiek van weerloosheid stel die leser egter in staat om etiese vrae oor die manier hoe die Bybel gebruik word, dit wil sê, "Skrifbenadering" te vra. Dit is ook waaroor 'n etiek van Bybellees gaan, naamlik om diegene wat die Bybel vir ander lees, se leespraktyke te bevraagteken en ondersoek in te stel na die gevolge wat hierdie leespraktyke op ander mense het.

'n Hermeneutiek van weerloosheid het ten doel om die Bybelleser nie alleen bewus te maak van die persoon teenoor wie die Bybel verklaar word nie, maar ook van die gevolge wat sy/haar Bybelverklaring vir daardie persoon mag hê. Hierby ingesluit is dit wat Van der Walt "Skrifbenadering" noem: 'n verantwoordelikheid vir die

22 Van der Walt sê dit nie, maar ek dink die hele vroomheidsretoriek rondom die gewaande posisie van die vrou in die kerk (solank dit net nie op die preekstoel is nie) dra daartoe by dat baie vroue hulle eie onderdrukking begin internaliseer. 
interpretasiemodel waarmee die Bybel gelees word.23 'n Hermeneutiek van weerloosheid hou so 'n Bybelleser verantwoordelik vir wat in hierdie proses gebeur en stel die etiek daarvan in die openbaar.

In hierdie opsig toon Van der Walt (2008:758) 'n besondere oog vir die historiese. Hoewel hy versigtig is, 24 erken hy dat die Bybel nie in 'n tydlose lugleegte ontstaan het nie en dat die wêreld ook nie stilstaan nie. Wat hy nuut deur middel van 'n persoonlike refleksie op die tafel sit, is 'n doelbewuste verrekening van die politieke konteks waarbinne die Bybel gelees word. Hy verwoord dit treffend (2008:763; beklemtoning - GFS) wanneer hy verwys na die aandag wat die Ou Testament gekry het deur middel van die manier waarop die Afrikanervolk met Israel geïdentifiseer is: "selfs as uitverkore volk - asof uitverkiesing in die Bybel ooit ' $n$ statussimbool eerder as ' $n$ dienskneg-roeping is". 25

23 Schussler-Fiorenza (1988:15) praat van "an ethics of accountability that stands responsible not only for the choice of theoretical interpretive models, but also for the ethical consequences of the biblical text and its meanings". Sy verwys ook na 'n "ethics of historical reading" waarmee sy geregtigheid aan die teks in sy historiese omstandighede wil laat geskied. 'n Hermeneutiek van weerloosheid kan ook na die teks oorgedra word, sodat die teks self uiteindelik aan bod kom. Vergelyk Snyman (2007:139-150) waar verduidelik word hoe die Bybelteks as "ander" gelees kan word.

24 Van der Walt (2008:758) staan krities teenoor die postmoderne wat altyd-geldende waardes ontken. Ek verskil egter van hom in hierdie opsig, want ten spyte van die postmoderne se oproep tot relatiwiteit, kan dit nie algemeengeldende waardes ontkom nie. Trouens, om 'n postmodernis te wees, moet 'n mens uitgaan van die altyd-geldende waarheid dat die meesterverhaal nie so altyd-geldend is nie! Miskien lê die probleem in die woord relatiwiteit wat in die Gereformeerde dampkring as relativisme verstaan word en al te maklik aangewend word om ongemaklike standpunte af te weer.

25 Die rol van die uitverkiesing in die teologiese regverdiging van apartheid moet nie onderskat word nie. Trouens, binne die hele kolonialisering van Afrika het dit 'n taamlike groot rol gespeel. Antjie Krog (2009:185) verwoord dit soos volg wanneer sy Afrika se interconnectedness kontrasteer met die uitsluiting van niegelowiges uit Christelike huise.

If I understand Kwame Gyeke correctly, I think the community in African terms is more fluid and more inclusive, with its variety of simultaneous links and networks woven through clanship, cattle, marriage, initiation and rituals. But of course there is tension. African intellectuals like Tiyo Soga complained already in the nineteenth century that wholeness' was destroyed by the entry of Christianity into Southern Africa; note: not through Christianity itself, but because Christians excluded non-believers from their houses - albeit on missionary orders. 
'n Hermeneutiek van weerloosheid probeer om aan hierdie diensknegroeping gestalte te gee. In so 'n hermeneutiek is die fokus eerder op die gevolge wat 'n bepaalde interpretasie op ander mag hê as op 'n (self)regverdiging vir 'n bepaalde lees. Ten aansien van die swart ander met wie die Bybel tans op kerklike vergaderings gelees word, en gegewe ons betrokkenheid by apartheid in die verlede, asook die epistemiese en beskawingsbreuk wat apartheid veroorsaak het, is hierdie geen maklike proses nie. Perkinson verwys in sy boek White theology: outing supremacy in modernity (Perkinson, 2004:34) na die proses as 'n "coming to consciousness of oneself as white [that] involves daring to look into black eyes and not deny the reflection". Dit hou in 'n "confrontation with the embarassment of having already been 'found out' by one's ... most frightening other". 26

\title{
4. Slotopmerkings
}

'n Hermeneutiek van weerloosheid het in die eerste plek betrekking op die Bybelleser wat in die Bybelleesproses met ander mense die mag het, hetsy vanweë meerdere kennis, hetsy uit hoofde van 'n magsposisie in die kerklike struktuur, of hetsy as gevolg van die gewone uitleef van die amp van die gelowige. In die tweede plek het hierdie hermeneutiek ook betrekking op die weerlose self, wat nie net ander weerloses ontmoet nie, maar ook die een wat in 'n magsposisie kom, se weerloosheid moet raaksien. Dit skep 'n atmosfeer waarbinne die implikasies van Bybelverklaring ernstig deur middel van kritiese beoordeling opgeneem kan word. Teenoor die naakte selfsug, wat Van der Walt meen die Afrikaner met blindheid geslaan het, stel ek die erkenning van die weerlose ander in die ontmoeting as korrektief voor. 'n Hermeneutiek van weerloosheid maak Bybellesers bewus van die effek van weerloosheid wat hulle Bybellees op ander mense kan hê. Terselfdertyd, in die bewusmaking van die weerloosheid van die ander, skep 'n hermeneutiek van weerloosheid

Hoe moeilik dit is, wys Du Preez (2009) in sy rubriek op News24:

\begin{abstract}
Many whites enjoyed it when the Judge President of the Western Cape, John Hlophe, demonstrated his utter unsuitability to be a judge of the high court by his racist utterances to white lawyers, by questionable business decisions and by trying to influence judges of the Constitutional Court to be pro-Zuma. You see, those whites said. Black lawyers and others have formed the Justice for Hlophe Alliance and call every single white person who wonders whether Hlophe would be such a great choice as Chief Justice as a despicable racist. Hlophe has now become a national symbol of black pride just because so many whites don't like him. At the Judicial Services Commission prominent black lawyers harass all white applicants for judicial positions simply because their skins are of a pale hue.
\end{abstract}


'n houding van weerloosheid by die Bybelleser, waardeur die Bybelleser hom-/haarself oopstel vir kritiek en van bevoorregting afstand doen. 27

'n Laaste woord egter oor die ander soort weerloosheidstelling wat besig is om te gebeur na aanleiding van regstellende aksie en grondhervorming. Apartheid het die swart ander weerloos gestel as gevolg van 'n groepsgebiedewet, 'n ontugwet en 'n werksreserveringwet. In 'n postapartheidstelsel word mense wat voordeel uit bogenoemde drie wette geput het, skielik weerloos gemaak. Hierdie soort weerloosheid is egter iets anders as die weerloosheid waarvan sprake is in 'n hermeneutiek van weerloosheid, omdat dit binne 'n raamwerk van geregtigheid plaasvind. Die weerloosheid waarvan in 'n hermeneutiek van weerloosheid sprake is, is as gevolg van ongeregtigheid. Die weerloosheid as gevolg van regstellende aksie en grondhervorming behoort op 'n pastorale vlak hanteer te word. Waar dit wel binne 'n hermeneutiek van weerloosheid sal begin funksioneer, is ten aansien van die swart ander wat vanuit 'n magsposisie die wit weerlose ander ontmoet. Dit is egter ' $n$ verantwoordelikheid wat op die swart ander se pad is en waarop ek as wit, Afrikaanssprekende, Westerse, middelklas, postkoloniale, postmoderne, heteroseksuele man nie 'n reg het nie.

Waar die GKSA groot strukturele treë geneem het in die eenwording met die kerke onder ander bevolkingsgroepe, is dit dalk nodig om bewus te wees van die weerloosheid van die ander en ons eie diensbaarheid wanneer ons die Bybel met ons inheemse Afrikabroeders en susters lees. 28

\section{Geraadpleegde bronne}

ANDERSON, C.B. 2009. Ancient laws and contemporary controversies: the need for inclusive biblical interpretation. Oxford: Oxford University Press.

ATEEK, N.S. 1991. A Palestinian perspective: the Bible and liberation. (In Sugirtharajah, R.S., ed. Voices from the margin: interpreting the Bible in the Third World. Maryknoll: Orbis. p. 280-286.)

27 Hierdie insig is te danke aan een van die anonieme kritiese lesers van die artikel gedurende die keuringsproses.

28 Die voorsetsel met is nie om dowe neute nie. Waar 'n sinode die Bybel vir die gemeentes in kerkverband interpreteer, veronderstel 'n lees met ander mense 'n ander werkswyse wat veral daarop neerkom om skanse af te breek en kontekste waarbinne Bybellees plaasvind, doelbewus in die lees te verdiskonteer. Daniel Patte se Global Bible commentary (2004) is 'n goeie voorbeeld. 
BOTHA, J. 1986. Die gereformeerde Skrifbeskouing en moderne metodes van verklaring van die Nuwe Testament. Koers, 51(3):259-286.

BREED, D.G., VAN RENSBURG, J.J. \& JORDAAN, G.J.C. 2008. Manlik en vroulik in die kerk: geslagtelikheid en die besondere dienste. Potchefstroom: Potchefstroomse Teologiese Publikasies.

BRUEGGEMANN, W. 2002. The abcs of Old Testament theology in the US. Zeitschrift für die alttestamentliche Wissenschaft, 114(3):412-432.

DEIST, F.E. 1994. The dangers of Deuteronomy: a page from the reception history of the Book. (In Martínez, F.G., Hillhorst, A. \& Van Ruiten, J.T.A., eds. Studies in Deuteronomy. Leiden: Brill. p. 13-29.)

DEIST, F.E. 2000. The material culture of the Bible: an introduction. Ed. with a preface by R.P. Carroll. Sheffield: Sheffield Academic Press. (The Biblical Seminar 70.)

DU PREEZ, M. 2009. Non-racial country? Non-sense. News24. Electonic version. http://www.news24.com/Content/Columnists/MaxduPreez/1033/ 4140cd03c8b7438f84d7eabb0cade9e7/05-08-200909-08/Nonracial_country_Non-sense Date of access: 5 Aug. 2009.

ESCOBAR, A. 2007. Worlds and knowledges otherwise: the Latin American Modernity/Coloniality Research Program. Cultural studies, 21(2 \& 3):179210.

FENSHAM, F.C. 1962. Widow, orphan and the poor in ancient Near Eastern legal and wisdom literature. Journal of Near Eastern studies, 21:129-39, April.

HEXHAM, I. 1981. The irony of apartheid: the struggle for national independence of Afrikaner Calvinism against British Imperialism: text and studies in religion. Vol. 8. New York: Mellen.

JANSE VAN RENSBURG, F. 2006. Die tydgerigtheid van die Bybel en die etiek van Bybellees: respons op die artikel van Gerrie Snyman. In die Skriflig, 40(4):745-769.

KROG, A. 2009. Begging to be black. Cape Town: Struik.

KRÜGER, P.P. \& JORDAAN, G.J.C. 2009. Só het Doppers besluit oor vroue. Beeld: 28 Jul. http://jv.news24.com/Beeld/In-Diepte/0,,3-67_25425 49,00. html Datum van gebruik: 28 Jul. 2009.

LEVINAS, E. 1969. Totality and infinity: an essay on exteriority. Trans. by A. Lingis. Pittsburgh: Duquesne University Press.

LEVINAS, E. 1981. Otherwise than being or beyond essence. Trans. by A. Lingis. London: Nijhoff.

LEVINAS, E. 1985. Ethics and infinity: conversations with Philippe Nemo. Trans. by R.A. Cohen. Pittsburgh: Duquesne University Press.

LEVINSON, B.M. 2008. Reading the Bible in Nazi Germany: Gerhard von Rad's attempt to reclaim the Old Testament for the church. Interpretation 62(3): 238-253.

LOHFINK, N. 1998. Landeroberung und Heimkehr: hermeneutisches zum heutigen Umgang mit dem Josuabuch. (In Janowski, B. \& Welker, M., Hrsg. Biblische Hermeneutik. Neukirchen: Neukirchener. S. 3-24.) (Jahrbuch für Biblicsche Theologie 12.)

PATTE, D. 2004. Global Bible commentary. Nashville: Abingdon.

PATTERSON, R.D. 1973. The widow, orphan and the poor in the Old Testament and the extra-biblical literature. Bibliotheca sacra, 130(519): 223-234. 
PERKINSON, J. 2004. White theology: outing supremacy in modernity: black religion/womanist thought/social justice. New York: Palgrave.

PHILLIP, G. \& FEWEL, D.N., eds. 1997. Bible and ethics of reading. Atlanta: Scholars. (Semeia 77.)

PRIOR, M. 1997. The Bible and colonialism: a moral critique. Sheffield: Sheffield Academic Press.

QUIJANO, A. 2007. Coloniality and modernity/rationality. Cultural studies, 21(2 \& 3):168-178.

SCHÜSSLER FIORENZA, E. 1988. The ethics of Biblical interpretation: decentering biblical scholarship. Journal of biblical literature, 107:3-17.

SNYMAN, G.F. 2006. Homoseksualiteit en tydgerigtheid: 'n etiek van Bybellees? In die Skriflig, 40(4):715-744.

SNYMAN, G.F. 2007. Om die Bybel anders te lees: 'n etiek van Bybellees. Pretoria: Griffel Media.

SNYMAN, G.F. 2011. "Om die Bybel sensitief en in sy rykdom te lees" - in gesprek met Amie van Wyk. In die Skriflig, 45(1):759-789.

THELLE, R.T. 2007. The biblical conquest account and its modern hermeneutical challenges. Studia theologica, 61:61-81.

VAN DER WALT, T. 2008. Hoe moet 'n Gereformeerde teoloog met die Bybel omgaan? In die Skriflig, 42(4):755-771.

VAN DEVENTER, H.J.M. 2010. Eerder anders as elders: Gerrie Snyman se bydrae in die konteks van die gereformeerde teologie. Verbum et ecclesia, 31(1), Art. \#306, 7 pages. DOI: 10.4102/ve.v31i1.306.

VON RAD, G. 1982. Old Testament theology. Vols. 1 \& 2. London: SCM.

WARRIOR, R.A. 1991. A native American perspective: Canaanites, cowboys, and Indians. (In Sugirtharajah, R.S., ed. Voices from the margin: interpreting the Bible in the Third World. Maryknoll: Orbis. p. 286-956.)

\section{Kernbegrippe:}

apartheid

hermeneutiek

mag

resepsiekritiek

sesde gebod

weduwees en wese

\section{Key concepts:}

apartheid

hermeneutics

power

reception criticism

sixth commandment

widows and orphans 